\title{
The Individual Deployment of Systems Development Methodologies
}

\author{
Magda Huisman ${ }^{1}$ and Juhani Iivari ${ }^{2}$ \\ ${ }^{1}$ Department of Computer Science and Information Systems, Potchefstroom \\ University for $\mathrm{CHE}$, \\ Private Bag X6001, Potchefstroom, 2531, South Africa \\ rkwhmh@puknet.puk.ac.za \\ ${ }^{2}$ Department of Information Processing Science, University of Oulu \\ P.O.Box 3000, 90014 Oulun yliopisto, Finland \\ juhani.iivari@oulu.fi
}

\begin{abstract}
This paper reports results of a survey that investigated factors affecting the deployment of systems development methodologies by individual systems developers. The results show that relative advantage, compatibility and trialability of a systems development methodology, an individual's experience in systems development and his/her experience in systems development methodologies, management support and peer developer support, and uncertainty about the continued existence of the IS department significantly influence the deployment of systems development methodologies.
\end{abstract}

\section{Introduction}

There exists a widespread belief that adherence to systems development methodologies (SDM) is beneficial to an organization ([7],[13]). This belief is manifested in the pressure that practitioners face today to use SDM [7]. Despite the high investment in the development of SDM and the pressure to use it, their practical usefulness is still a controversial issue ([7],[20],[28]). Recent surveys on their use also indicate quite consistently that many organizations claim that they do not use any methodologies ([13],[2],[8]). Apart from this, we do not know why SDM are used or not used, and what factors influence its use and effectiveness.

In this paper we investigate the deployment of SDM among individual systems developers. A decision by IS management to adopt SDM in an IS department does not guarantee that all developers will use the methodology, or that they will use it to its full potential. The purpose of this paper is to determine which factors influence the individual deployment of SDM. 


\section{Conceptual Research Model and Research Hypotheses}

\subsection{Theoretical Background}

Most of the previous research into SDM did not have any theoretical orientation but the idea had been just to report the state of use of SDM and techniques in purely descriptive terms, e.g. [13] and [2]. In general terms the present work is influenced by the diffusion of innovations (DOI) theory [35], which is becoming an increasingly popular reference theory for empirical studies of information technologies ([5],[31]).

More specifically, our work is based on the IS implementation model suggested by Kwon and Zmud [23]. They combined IS implementation research and the DOI theory. This resulted in an enlarged model that identifies five categories of factors affecting IS implementation: individual factors, structural (organisational) factors, technological factors (innovation characteristics), task-related factors, and environmental factors. This categorisation provides the overall conceptual framework for our work (Figure 1). However, our selection of individual factors does not follow the model of [23] precisely for two reasons. Firstly, their list of 23 factors is quite comprehensive to be tested in one study. Secondly, we wished to identify factors that are more specific to SDM than many of the factors they identified.

According to the tri-core model presented by [36], SDM are IS technological process innovations of Type $1 \mathrm{~b}$, which focus on the technical core of the IS department, and change the nature of IS work. The social system that we study is an organisation. In terms of [35], SDM are contingent innovations with organisations as primary adopting units and individuals as secondary adopting units. [4] stresses that a distinction should be made between the adoption and acquisition of technology at the organisational level and its adoption and implementation at the individual level. In this study we will focus on the individual systems developer as the adopting unit. The adoption and implementation at the organisational level are reported in another study.

The DOI theory has also been criticised. [5] points out that it has mainly addressed individual adoption of relatively simple innovations. Despite of our recognition that SDMs are contingent innovations [35], our focus in this paper lies on individual adoption of SDM. It is also obvious that SDM are fairly complex innovations. They are technologies of Type 2 [5], which are characterised by a high knowledge burden or high user interdependencies. This means that our study tests the validity of DOI theory partly outside its major focus area. Therefore the detailed hypotheses concerning the deployment of SDM, derived from the classical DOI theory, are quite tentative.

As pointed above there is not much theoretically oriented empirical research into the adoption of SDM, on which we can draw in our discussion of detailed hypotheses. To compensate this we mainly use existing empirical research on the adoption of CASE technology. There are two reasons for this. Firstly, CASE tools represent relatively complex technologies which are contingent innovations just as SDM. Secondly, the methodology companionship of CASE tools [38] implies that their adoption includes a significant aspect of SDM. 


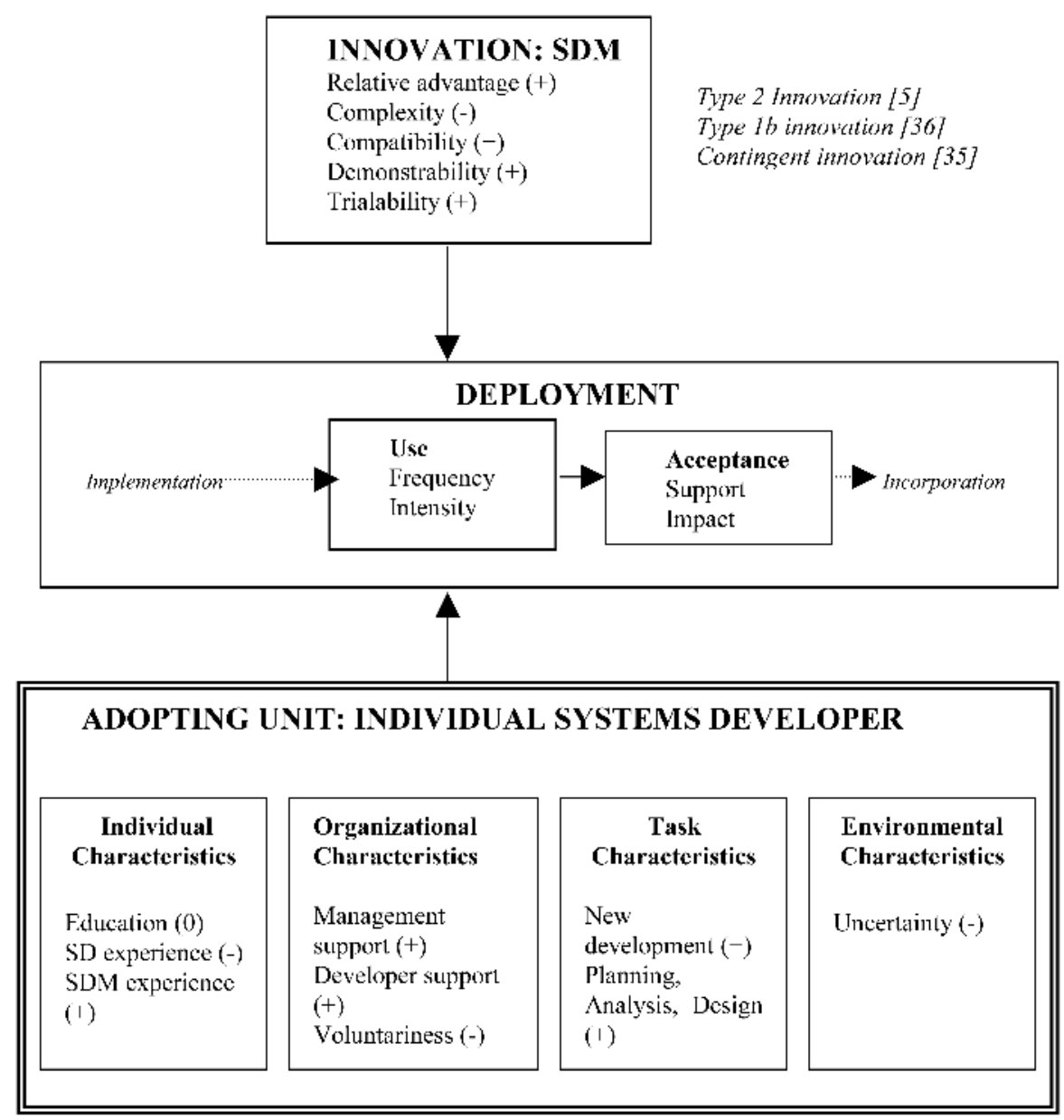

Fig. 1 Conceptual research model for the individual deployment of SDM

\subsection{The Innovation: SDM}

Trying to define SDM is no easy task. There is no universally accepted, rigorous and concise definition of SDM ([1],[39],[18]). [1] argues that the term methodology is a wider concept than the term method, as it has certain characteristics that are not implied by method, i.e. the inclusion of a philosophical view. We use the term „methodology“ to cover the totality of systems development approaches (e.g. structured approach, object-oriented approach), process models (e.g. linear life-cycle, spiral models), specific methods (e.g. IE, OMT, UML) and specific techniques.

Individuals' responses to an innovation are primarily influenced by attributes of the innovation and the implementation process [25]. The characteristics of SDM that we will study was suggested by [35], namely perceived relative advantage, compatibility, complexity, trialability and observability. 


\section{Relative advantage}

Relative advantage is the degree to which an innovation is perceived as being better than the idea it supersedes [35]. After a decade's intensive research on TAM [3] in particular, there is significant empirical evidence that relative advantage or perceived usefulness [27] is positively related to innovation use, even though [17] discovered it to have a significant relationship with CASE usage only at the organizational level but not at the individual level. This overwhelming evidence leads us to the following hypothesis:

- H1: There is a positive relationship between relative advantage and the individual deployment of SDM.

\section{Complexity}

Complexity is the degree to which an innovation is perceived as difficult to understand and use [35]. It is generally believed that the more complex an individual perceives an innovation to be before using it, the less likely it is that the innovation will be adopted and implemented. Although perceived complexity has generally been assumed to be negatively related to the adoption of innovations ([3],[27],[35]), the empirical results regarding the relationship between perceived complexity (or perceived ease of use when inversed [27] ) and use has been inconclusive [9]. This is also the case in the adoption of CASE tools ([26],[17]). Despite the inconclusive empirical evidence, we postulate in accordance with the DOI theory [35] and TAM [3] the following:

- H2: There is a negative relationship between complexity and the individual deployment of SDM.

\section{Compatibility}

Compatibility is the degree to which an innovation is perceived as being consistent with the existing values, past experiences and needs of potential adopters, and it is positively related to innovation use [35]. Compatibility is sometimes described as the „fit" between an innovation and a particular context, which implies that an innovation must match its context in order to be effective. [26] remarks that a detailed assessment should be made of the "fit" between CASE methodology and the systems development tasks it is designed to support, when studying the acceptance of CASE methodology. [17] also found some evidence for the significance of compatibility for CASE usage. Following the DOI theory, we postulate the next hypothesis as follows:

- H3: There is a positive relationship between compatibility and the individual deployment of SDM.

\section{Demonstrability}

[35] uses the term „observability“ and defines it as the degree to which the results of an innovation are visible to others. He argues that the easier it is for individuals to see the results of an innovation, the more likely they are to adopt it. [27] found that „observability“ as originally defined by Rogers consist of two constructs, namely result demonstrability and visibility. Software-dominant innovations are less visible than hardware-dominant innovations ([27],[35]). Therefore we used the construct for result demonstrability and we postulate the following hypothesis: 
- H4: There is a positive relationship between demonstrability and the individual deployment of SDM.

\section{Trialability}

[35] defines trialability as the degree to which an innovation may be experimented with on a limited basis. He argues that innovations, which are trialable, will be adopted more quickly, because it represents less uncertainty to the individual. We formulate the fifth hypothesis:

- H5: There is a positive relationship between trialability and the individual deployment of SDM.

\subsection{Innovation Diffusion Process}

Our main focus is on the deployment of SDM, which is related to the implementation and confirmation stages of the innovation-decision process as described by [35]. Since deployment is part of the post-implementation stage, we use the description of [26] in our conceptual research model. After implementation, deployment will follow, which in turn is followed by incorporation. We visualise deployment as two stages, namely use followed by acceptance.

Use will be studied along two dimensions, namely frequency of use and intensity of use. The acceptance of SDM will be studied from two perspectives, namely their impact on systems development and the perceived support it provides [26]. When studying the impact of SDM, we will focus on their impact on both the developed system and the development process ([14],[39]). The support that SDM provide will be studied along three dimensions, namely the perceived support as production technology, control technology, and cognitive/co-operative technology [15]. In Table 1 we summarise the different perspectives that we use to study deployment.

Table 1. Perspectives used to study deployment of SDM

\begin{tabular}{|l||l|l|}
\hline \multicolumn{1}{|l||}{ Use } & Acceptance \\
\hline & Support provided & Impact \\
\hline \hline Frequency of use & Production technology & $\begin{array}{l}\text { Quality of developed } \\
\text { system } \\
\text { Quality and productivity } \\
\text { of development process }\end{array}$ \\
\hline & $\begin{array}{l}\text { Control technology } \\
\text { Cognitive/co-operative } \\
\text { technology }\end{array}$ & \\
\hline
\end{tabular}

\subsection{Individual Characteristics}

\section{Education}

Empirical results regarding the influence of education on the innovation process have been inconclusive. [23] states that negative associations have been found between education and innovation usage, mixed results have been reported for performance, 
and negative associations have been found between education and satisfaction with the innovation. This leads to the next hypothesis in its null form:

- H6: There is no relationship between education and the individual deployment of SDM.

\section{Experience in systems development}

Research suggests that the experience profile of an individual is an important factor in the acceptance and use of SDM. The findings suggest that inexperienced developers are more likely to use SDM and CASE tools ([24],[29]), while experienced developers may resist using them [37]. We formulate the following hypothesis:

- H7: There is a negative relationship between an individual's experience in systems development and the individual deployment of SDM.

\section{Experience in SDM}

Contrary to Hypotheses H7 [25] argues that experienced developers are more likely to use SDM as they would be more aware of the benefits. Assuming that SDM have benefits, one can assume experienced developers who have experience of using a particular SDM to be more likely to use SDM. Therefore, we postulate the following hypothesis:

- H8: There is a positive relationship between an individual's experience with SDM and the individual deployment of SDM.

\subsection{Task Characteristics}

SDM are primarily used in the development of new systems, and are often not as helpful in the enhancement of operational systems [30]. Furthermore, SDM are most effective for analysing the functionality of a newly developed system [21]. We formulate the next hypotheses as follows:

H9: There is a positive relationship between the time an individual spends on the development of new systems and the individual deployment of SDM.

H10: There is a positive relationship between the time an individual spends on the planning, analysis and design of a new system and the individual deployment of SDM.

\subsection{Organisational Characteristics}

Individual systems developers do not work and deploy SDM in vacuum but under various social influences. The Theory of Reasoned Action [6] posits that an individual's behavior is influenced by his/her perception of the social pressure (subjective norm) to perform or not to perform the behavior. Subjective norm is defined as a multiplicative function of his/her normative beliefs (i.e. perceived expectations of specific referent individual and groups) and his/her motivation to comply with these expectations. The relevant referent groups may be top managers, supervisors, peers and friends. [22] tested the influence of a number of referent groups on the subjective norms of potential adopters and users of Microsoft Windows 3.1 software. They found that top management, supervisors and peers significantly underlie subjective norms for both groups, and additionally local computer specialists 
for users. On the other hand, they discovered subjective norms to have a significant influence on behavioral intention to adopt but not on behavioral intention to continue using. In line with [22] we will focus on manager influence, including both top management and IT managers, and peer developer influence. We do not make a distinction between potential adopters and users since SDM deployment concerns continued use, rather than potential adoption. Partly contrary to [22] findings we assume management and peer support to influence positively continued use of SDM, as explained below.

\section{Management Support}

Management support is consistently reported to facilitate IS implementation [10]. When we consider SDM, [21], [33], and [34] list a lack of management commitment as one of the biggest obstacles to implementing SDM. [17] also reports management support to have significant effects on CASE usage both at the individual and organizational level. This leads to our next hypothesis:

- H11: There is a positive relationship between management support and the individual deployment of SDM.

\section{Developer support}

To our knowledge there is not much previous research on peer influence on the use and acceptance of innovations in general, IT innovations more specifically, and SDM innovations in particular. Despite that we propose the following hypothesis:

- H12: There is a positive relationship between developer support for the systems development methodology and the individual deployment of SDM.

\section{Voluntariness}

Voluntariness is the degree to which an innovation is perceived as being voluntary or of free will [27]. When we consider contingent innovations, the secondary adopters rarely have complete autonomy regarding their adoption and use in the workplace. Furthermore, SDM are complex innovations, and unless management declares their use mandatory, systems developers will have difficulty to fit them into their tight schedule. [17] found strong support for the negative influence of voluntariness on CASE usage and [11] reports a strong negative influence of voluntariness on the use of the Personel Software Process innovation. This leads to our next hypothesis:

H13: There is a negative relationship between voluntariness and the individual deployment of SDM.

\subsection{Environmental Characteristics}

\section{Uncertainty}

The deployment of SDM can be justified as an investment in the maintainability of systems, supported by proper documentation and proper modular structuring. Therefore, if the future of the IS department is uncertain or under threat, it may decrease the motivation to deploy the SDM. Unfortunately, to our knowledge there is no previous work on this relationship. [32] concluded that users may be unwilling to 
support new initiatives in an IS department in which they have limited confidence. On the other hand, uncertainty is believed to stimulate innovation through an organisation's effort to survive and grow [23]. On the whole, we formulate our next hypothesis as follows:

- H14: There is a negative relationship between the uncertainty about the continued existence of an IS department and the individual deployment of SDM.

\section{Research Design}

\subsection{The Survey}

This study is part of a larger survey on the deployment of SDM in South Africa, which was conducted between July and October 1999. The 1999 IT Users Handbook (the most comprehensive reference guide to the IT industry in South Africa) was used and the 443 listed organizations were contacted via telephone to determine if they were willing to participate in the study. 213 organizations agreed to take part. A package of questionnaires was sent to a contact person in each organization who distributed it. This package consisted of one questionnaire to be answered by the IT manager, and a number of questionnaires to be answered by individual systems developers in the organization. The response rate of the survey was as follows: 83 organizations (39\%), 234 developers $(26 \%)$ and 73 managers $(34 \%)$ responded. The responses came from organisations representing a variety of business areas, manufacturing (33\%) and finance/banking/insurance (15\%) as the major ones. At the individual level the respondents reported considerable experience in SD, 22\% between 3 and 5 years, $23 \%$ between 5-19 years and 38\% more than 10 years.

\subsection{Measurement}

\subsubsection{Measurement of Dependent Variable: Deployment}

In Table 2 we summarise the measurement of the different aspects that we used to study deployment. Frequency of use was measured using a question of how frequently the respondent needed or applied SDM knowledge (never; once a month or less: a few times in a month; several times in a week; every working day). Intensity of use was measured as the maximum of the individual usage of 29 listed methods, possible other commercial methods and possible in-house developed methods.

One might also ask what independent variables explain deployment in total. To answer this question, factor analysis on the seven aspects of deployment was performed, and this resulted in one factor with a reliability of 0.82 . To measure total individual deployment we used the factor scores resulting from the factor analysis. 
Table 2. Measurement of deployment

\begin{tabular}{|l|l|l|l|}
\hline $\begin{array}{l}\text { Deployment } \\
\text { aspects }\end{array}$ & Perspectives & Measurement & Reliability \\
\hline \hline Use & Frequency of use & 2 items & 0.84 \\
\hline \hline Support & Intensity of use & & \\
\hline & Production technology & 11 items (see [19]) & 0.94 \\
\hline & Control technology & 9 items (see [19]) & 0.94 \\
\hline $\begin{array}{l}\text { Cognitive/co-operation } \\
\text { Iechnology }\end{array}$ & 11 items (see [19]) & 0.91 \\
\hline & $\begin{array}{l}\text { Quality of developed } \\
\text { systems }\end{array}$ & 8 items (see [19]) & 0.95 \\
\hline & $\begin{array}{l}\text { Quality and productivity } \\
\text { of development process }\end{array}$ & 10 items (see [19]) & 0.94 \\
\hline
\end{tabular}

\subsubsection{Measurement of Independent Variables}

The measurement of the independent variables is summarised in Table 3. As Table 3 shows most measures were adopted from earlier research, and they have high reliability. The two items of uncertainty concerned the threat that the IS department is disbanded and the uncertainty of the future of the IS department in the organization.

\subsection{Data Analysis}

Data analysis was performed on the developer responses using Statistica (version 5) software. In the first analysis the seven different aspects of deployment was treated separately as the dependent variables. To identify the most important independent variables that explain the dependent variables, best subset multiple regression analysis was performed. In a second analysis, total deployment was treated as the dependent variable, and best subset multiple regression was performed.

Multiple regression analysis assumes interval or ratio scale measurement, linearity, homoscedasticity, i.e. the constancy of the residual terms across the values of the predictor variables, independence of residuals, normality of residuals, and no multicollinearity [12]. These assumptions were tested and no violations were detected.

\section{$4 \quad$ Results}

The results of the best subset multiple regression analysis with the seven different aspects of deployment of SDM as the dependent variables are presented in Table 4 and Table 5.

The last column of Table 5 contains the results of the regression analysis where total deployment was the dependent variable. To confirm the results of the regression analysis with total deployment as the dependent variable, we performed canonical analysis. Canonical analysis is used to determine the relationship between two sets of variables. The seven different aspects of deployment formed the first set, and the 
fourteen independent variables the second set. The resulting Canonical $\mathrm{R}$ was 0.90 at the level of $p \leq 0,001$, and the eigenvalue of the first root was 0.81 . The factor structures of the two sets confirmed the results of the factor analysis and the regression analysis.

Table 3. Measurement of independent variables

\begin{tabular}{|c|c|c|c|}
\hline Type & Characteristic & Measurement & Reliability \\
\hline \multirow[t]{5}{*}{$\begin{array}{l}\text { Innovation } \\
\text { Characteristics }\end{array}$} & $\begin{array}{l}\text { Relative } \\
\text { advantage }\end{array}$ & 5 items (adapted from [27]) & 0.94 \\
\hline & Complexity & 3 items (adapted from [27]) & 0.88 \\
\hline & Compatibility & 3 items (adapted from [27]) & 0.91 \\
\hline & Demonstrability & 3 items (adapted from [27]) & 0.85 \\
\hline & Trialability & 2 items (adapted from [27]) & 0.70 \\
\hline \multirow[t]{3}{*}{$\begin{array}{l}\text { Individual } \\
\text { Characteristics }\end{array}$} & Education & $\begin{array}{l}\begin{array}{l}\text { Highest qualification ob- } \\
\text { tained }\end{array} \\
\end{array}$ & 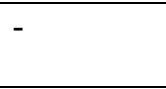 \\
\hline & $\begin{array}{l}\text { Experience in } \\
\text { systems } \\
\text { development }\end{array}$ & Number of years & - \\
\hline & $\begin{array}{l}\text { Experience in } \\
\text { the use of SDM }\end{array}$ & Number of years & - \\
\hline \multirow[t]{2}{*}{$\begin{array}{l}\text { Task } \\
\text { Characteristics }\end{array}$} & $\begin{array}{l}\text { Time spent on } \\
\text { the development } \\
\text { of new applica- } \\
\text { tions }\end{array}$ & $\%$ & 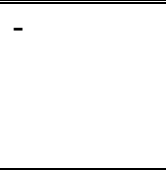 \\
\hline & $\begin{array}{l}\text { Time spent on } \\
\text { planning, analy- } \\
\text { sis, and design } \\
\text { activities }\end{array}$ & $\%$ & - \\
\hline \multirow[t]{3}{*}{$\begin{array}{l}\text { Organisational } \\
\text { Characteristics } \\
\end{array}$} & $\begin{array}{l}\text { Management } \\
\text { support }\end{array}$ & 2 items (adapted from [17]) & 0.86 \\
\hline & $\begin{array}{l}\text { Developer sup- } \\
\text { port }\end{array}$ & 1 item & - \\
\hline & Voluntariness & 2 items (adapted from [27]) & 0.82 \\
\hline $\begin{array}{l}\text { Environmental } \\
\text { Characteristic }\end{array}$ & Uncertainty & 2 items & 0.90 \\
\hline
\end{tabular}

\section{Discussion and Final Comments}

In this paper our purpose was to study factors that influence the individual deployment of SDM. We identified fourteen possible factors, postulating fourteen hypotheses about their relationship with the individual deployment of SDM. These are summarised in Table 6. 
Table 4 Results of the regression analysis

\begin{tabular}{|c|c|c|c|c|c|}
\hline $\mathrm{N}=173$ & $\begin{array}{l}\text { Frequenc } \\
\mathrm{y} \text { of use }\end{array}$ & $\begin{array}{l}\text { Intensity } \\
\text { of use }\end{array}$ & $\begin{array}{l}\text { Support: } \\
\text { Productio } \\
\text { n techno- } \\
\text { logy }\end{array}$ & $\begin{array}{l}\text { Support: } \\
\text { Control } \\
\text { techno- } \\
\text { logy }\end{array}$ & $\begin{array}{l}\text { Support: } \\
\text { Cognitive/ } \\
\text { co-opera- } \\
\text { tion } \\
\text { technology }\end{array}$ \\
\hline $\begin{array}{l}\text { Relative } \\
\text { advantage }\end{array}$ & $0.34 * *$ & $0.24^{\prime}$ & $0.25^{* *}$ & $0.45 * * *$ & $0.49 * * *$ \\
\hline Complexity & & & 0.09 & & \\
\hline Compatibility & -0.15 & -0.20 & $0.20^{*}$ & 0.11 & \\
\hline Demonstrability & & $0.15^{\prime}$ & & & \\
\hline Trialability & 0.08 & 0.11 & 0.08 & $0.10^{\prime}$ & $0.12 *$ \\
\hline Education & & & 0.06 & & \\
\hline SD experience & $-0.17 *$ & & $-0.12^{*}$ & & \\
\hline $\begin{array}{l}\text { SDM } \\
\text { experience }\end{array}$ & $0.45 * * *$ & $0.21 * *$ & 0.10 & & 0.07 \\
\hline $\begin{array}{l}\text { Time: Develop } \\
\text { new applications }\end{array}$ & & & & & $0.10^{\prime}$ \\
\hline $\begin{array}{l}\text { Time: Planning, } \\
\text { Analysis, } \\
\text { Design }\end{array}$ & $0.23 * * *$ & & & & \\
\hline $\begin{array}{l}\text { Manager } \\
\text { support }\end{array}$ & $-0.16^{*}$ & & $0.29 * * *$ & $0.25 * * *$ & 0.10 \\
\hline $\begin{array}{l}\text { Developer } \\
\text { support }\end{array}$ & 0.10 & & $0.11^{\prime}$ & & $0.20 * *$ \\
\hline Uncertainty & -0.08 & & $-0.13 * *$ & $-0.15 * *$ & \\
\hline Voluntariness & $-0.13^{\prime}$ & & 0.07 & & \\
\hline $\mathrm{R}$ & 0.71 & 0.40 & 0.82 & 0.75 & 0.77 \\
\hline $\mathrm{R}^{2}$ & 0.51 & 0.16 & 0.68 & 0.57 & 0.60 \\
\hline Adjusted $\mathrm{R}^{2}$ & 0.48 & 0.13 & 0.66 & 0.56 & 0.58 \\
\hline $\mathrm{F}$ & $17.65^{* * *}$ & $6.60 * * *$ & $32.11 * * *$ & $45.28 * * *$ & $41.88 * * *$ \\
\hline
\end{tabular}

\subsection{Implications for Theory}

The above results shed new light into the factors affecting the deployment of SDM. Overall, they show that the classical DOI theory [35] is relevant and useful in the case of individual deployment of complex innovations such as SDM (see [5]). The results indicate that especially relative advantage, compatibility less systematically and trialability more weakly have significant positive relationships with the individual deployment of SDM. Relative advantage is positively related to all seven different aspects of individual deployment. This suggests that individual systems developers' decisions to deploy SDM mainly takes place on rational grounds. If a systems 
developer sees SDM to provide relative advantage he or she is prepared to use it and to derive the benefits of using it. While compatibilty is strongly related to the perceived impact of SDM on the developed system and the development process, it is perplexing that it has negative, although not significant, beta coefficients with the methodology use. One explanation may be that when a SDM is highly compatible with a developer's way of working, its use may be quite routine and even tacit. It may be that our items measuring methodology use were not fully able to capture this routine or tacit nature of SDM use. On the other hand, when a methodology is perceived to be compatible with one's way of working, its benefits are perceived to be higher in terms of its impact on the quality of the system to be developed and the development process. Although trialability is not significantly related to the many aspects of deployment, it is related to deployment in total. On the other hand, contrary to the predictions of the DOI theory, complexity and demonstrability were not significantly related to the individual deployment of SDM.

Table 5. Results of the regression analysis

\begin{tabular}{|l|l|l||l|}
\hline $\mathrm{N}=173$ & $\begin{array}{l}\text { Impact: } \\
\text { System }\end{array}$ & $\begin{array}{l}\text { Impact: } \\
\text { Process }\end{array}$ & $\begin{array}{l}\text { Total } \\
\text { deployment }\end{array}$ \\
\hline Relative advantage & $0.17^{\prime}$ & $0.39^{* * *}$ & $0.39^{* * *}$ \\
\hline Complexity & & & \\
\hline Compatibility & $0.44^{* * *}$ & $0.27^{* *}$ & $0.17^{*}$ \\
\hline Demonstrability & $0.10^{\prime}$ & & 0.06 \\
\hline Trialability & & 0.08 & $0.10^{*}$ \\
\hline Education & & 0.06 & \\
\hline SD experience & $-0.12^{*}$ & -0.09 & $-0.11^{*}$ \\
\hline SDM experience & & & $0.14^{* *}$ \\
\hline Time: Develop new applications & & 0.08 & 0.05 \\
\hline Time: Planning, Analysis, Design & & & \\
\hline Manager support & 0.10 & $0.18^{* *}$ & $0.16^{* *}$ \\
\hline Developer support & 0.08 & & $0.11^{\prime}$ \\
\hline Uncertainty & -0.07 & $-0.10^{\prime}$ & $-0.09^{*}$ \\
\hline Voluntariness & & 0.07 & \\
\hline \hline R & 0.76 & 0.78 & 0.86 \\
$\mathrm{R}^{2}$ & 0.58 & 0.60 & 0.74 \\
Adjusted R & & & \\
F & 0.56 & 0.58 & 0.73 \\
\hline
\end{tabular}

, $\mathrm{p} \leq 0,10 * \mathrm{p} \leq 0,05 \quad * * \mathrm{p} \leq 0,01 \quad * * * \mathrm{p} \leq 0,001$

Systems development experience was negatively related to the individual deployment of SDM. This is in accordance with earlier findings that methodologies are used more by beginners than experienced developers ([24],[29]). However, to complicate the situation, experience with SDM was positively related to the individual deployment of SDM. More experienced systems developers had more experience with $\mathrm{SDM}$ as indicated by the correlation coefficient $(\mathrm{r}=0,47, \mathrm{p} \leq 0,001)$. So, as individuals they comprise two characteristics that are opposite to each other with 
regard to the deployment of SDM: experience with SDM being positively associated with the deployment and SD experience being negatively associated with the deployment. When we consider the different aspects of deployment the picture becomes a bit clearer. SD experience is mainly negatively related to the perceived impact of SDM on the developed system and the development process, and SDM experience is strongly positively related to the use of SDM.

Table 6. Summary of results

\begin{tabular}{|c|c|c|}
\hline H1 & $\begin{array}{l}\text { There is a positive relationship between relative } \\
\text { advantage and the individual deployment of SDM }\end{array}$ & $\begin{array}{l}\text { Strongly } \\
\text { supported }\end{array}$ \\
\hline $\mathrm{H} 2$ & $\begin{array}{l}\text { There is a negative relationship between complexity } \\
\text { and the individual deployment of SDM }\end{array}$ & Not supported \\
\hline H3 & $\begin{array}{l}\text { There is a positive relationship between com- } \\
\text { patibility and the individual deployment of SDM }\end{array}$ & $\begin{array}{l}\text { Partially } \\
\text { supported }\end{array}$ \\
\hline $\mathrm{H} 4$ & $\begin{array}{l}\text { There is a positive relationship between demonstra- } \\
\text { bility and the individual deployment of SDM }\end{array}$ & Not supported \\
\hline H5 & $\begin{array}{l}\text { There is a positive relationship between trialability } \\
\text { and the individual deployment of SDM }\end{array}$ & Weakly supported \\
\hline H6 & $\begin{array}{l}\text { There is no relationship between education and the } \\
\text { individual deployment of SDM }\end{array}$ & Supported \\
\hline $\mathrm{H7}$ & $\begin{array}{l}\text { There is a negative relationship between an in- } \\
\text { dividual's experience in systems development and } \\
\text { the individual deployment of SDM }\end{array}$ & $\begin{array}{l}\text { Partially } \\
\text { supported }\end{array}$ \\
\hline H8 & $\begin{array}{l}\text { There is a positive relationship between an in- } \\
\text { dividual's experience with SDM and the individual } \\
\text { deployment of SDM }\end{array}$ & $\begin{array}{l}\text { Partially } \\
\text { supported }\end{array}$ \\
\hline H9 & $\begin{array}{l}\text { There is a positive relationship between the time an } \\
\text { individual spends on the development of new } \\
\text { systems and the individual deployment of SDM }\end{array}$ & Not supported \\
\hline $\mathrm{H} 10$ & $\begin{array}{l}\text { There is a positive relationship between the time an } \\
\text { individual spends on the planning, analysis and } \\
\text { design of a new system and the individual } \\
\text { deployment of SDM }\end{array}$ & Not supported \\
\hline H11 & $\begin{array}{l}\text { There is a positive relationship between manage- } \\
\text { ment support and the individual deployment of } \\
\text { SDM }\end{array}$ & Supported \\
\hline H12 & $\begin{array}{l}\text { There is a positive relationship between developer } \\
\text { support for the systems development methodology } \\
\text { and the individual deployment of SDM }\end{array}$ & Weakly supported \\
\hline H13 & $\begin{array}{l}\text { There is a negative relationship between volun- } \\
\text { tariness and the individual deployment of SDM }\end{array}$ & Not supported \\
\hline H14 & $\begin{array}{l}\text { There is a negative relationship between the un- } \\
\text { certainty about the continued existence of an IS } \\
\text { department and the individual deployment of SDM }\end{array}$ & Weakly supported \\
\hline
\end{tabular}


The results also lend support for the significance of social influences on the individual deployment of SDM. A significant positive relationship was found between management support and the individual deployment of SDM. Furthermore, an almost significant positive relationship was found between developer support and the individual deployment of SDM. These results are in line with previous research on the adoption of complex innovations [5] and confirm earlier findings on the significance of management support in the case of software process improvement initiatives [16].

\subsection{Practical Implications}

The above results have clear practical implications. Assuming that deployment of SDM is desirable, one should attempt to ensure that the individual systems developers perceive the methodologies to have relative advantage and compatibility with their work. The potential benefits of a methodology and reasons for its introduction should be made clear and communicated to the systems developers. However, we do not believe that these perceptions can be changed using unilateral communication, but the benefits and compatibility should be discussed openly with systems developers. The significance of compatibility suggests that one should also be prepared to adapt and customise a methodology to fit the organization and the project as far as it does not threat the central reasons of introducing a methodology.

The trialability of SDM was also found significant. This would suggest that one should pay attention to the way of introducing a methodology. It can take place in pilot projects or applying only part of a methodology (e.g. starting from requirements engineering). As always in pilot projects one should pay attention to their selection as well to the selection of the participants. The participants should be motivated. Although it is not tested in this study, it would also be useful if they could serve as opinion leaders later, if the methodology is to be diffused more widely in the organisation. Referring to the significance of experience, it is important to ensure that the pilot project is as pleasant an experience as possible. The pilot project may be introduced as an opportunity to learn a new methodology that enhances and possibly updates the expertise of the participants (as could be the case when introducing some OO methodology).

It is also significant that management communicates its support for the SDM introduction and deployment. The results also suggest that uncertainty concerning the future of the IS department is detrimental to methodology deployment. Therefore, if the IS department is not under real threat, one should attempt to decrease such uncertainty.

\section{References}

1. Avison, D. E., Fitzgerald, G. (1995) Information Systems Development: Methodologies, Techniques and Tools, McGraw-Hill, Berkshire, England

2. Chatzoglou, P. D., Macaullay, L. A. (1996) Requirements capture and IS methodologies, Information Systems Journal, Vol. 6, pp. 209-225 
3. Davis, F. D., Bagozzi, R. P., Warshaw, P. R. (1989) User acceptance of computer technology: A comparison of two theoretical models, Management Science, Vol. 35, No. 8, pp. 982-1003

4. Dietrich, G. B., Walz, D. B., Wynekoop, J. L. (1997) The failure of SDT Diffusion: A Case for Mass Customization, IEEE Transactions on Engineering Management, Vol. 44, No. 4, pp. 390-398

5. Fichman, R. G. (1992) Information Technology Diffusion: A review of empirical research, in DeGross, J. I., Becker, J. D., Elam, J. J. (eds.) Proceedings of the Thirteenth International Conference on Information Systems, Dallas, TX, pp. 195-206

6. Fishbein, M., Ajzen, I. (1975) Belief, Attitude, Intention and Behavior: An Introduction to Theory and Research, Addison-Wesley, Reading, MA

7. Fitzgerald, B. (1996) Formalized SDM: a critical perspective, Information Systems Journal, Vol. 6, pp. 3-23

8. Fitzgerald, B. (1998) An empirical investigation into the adoption of SDM, Information \& Management, Vol. 34 , pp. 317-328

9. Gefen, D., Straub, D. W. (2000) The relative importance of perceived ease of use in IS adoption: A study of e-commerce adoption, Journal of the Association for Information Systems, Vol. 1, 2000

10. Ginzberg, M. J. (1981) Key recurrent issues in the MIS implementation process, MIS Quarterly, Vol. 5, pp. 47-59

11. Green, G. C. and Hevner, A. R., Perceived Control of Software Developers and its Impact on the Successful Diffusion of Information Technology, CMU/SEI-98SR-013, Carnegie Mellon, Software Engineering Institute, Pittsburgh, PA, 1999, http://www.sei.cmu.edu/pub/documents/98.reports/pdf/98sr013.pdf

12. Hair, J. F., Anderson, R. E., Tatham, R. L., Black, W. C. (1992), Multivariate Data Analysis with Readings, Macmillan, New York

13. Hardy, C. J., Thompson J. B., Edwards H. M. (1995) The use, limitations and customization of structured systems development methods in the United Kingdom, Information and Software Technology, Vol. 37, No. 9, pp. 467-477

14. Heineman, G. T., Botsford, J. E., Caldiera, G., Kaiser, G. E., Kellner, M. I., Madhavji, N. H. (1994) Emerging technologies that support a software process life cycle, IBM Systems Journal, Vol. 33, No. 3, pp. 501-529

15. Henderson, J. C., Cooprider, J. G. (1990) Dimensions of I/S planning and design aids: A functional model of CASE technology, Information Systems Research, Vol. 1, No. 3, pp. 227-254

16. Herbsleb, J., Zubrow, D., Goldenson, D., Hayes, W., Paulk, M. (1997) Software quality and the Capability Maturity Model, Communications of the ACM, Vol. 40, No. 6, pp. 30-40

17. Iivari J. (1996) Why are CASE Tools not used?, Communications of the ACM, Vol.39, No.10, pp. 94-103

18. Iivari, J., Hirscheim, R., Klein, H. K. (1999) Beyond Methodologies: Keeping up with Information Systems Development Approaches through Dynamic Classification, Proceedings of the $32^{\text {nd }}$, Hawaian International Conference on Systems Sciences, pp.1-10 
19. Iivari, J. and Huisman, M. (2001) The relationship between organisational culture and the deployment of systems development methodologies, in Dittrich, K., Geppert, A. and Norrie, M. C., Advanced Information Systems Engineering, Springer-Verlag, Berlin, 2001, pp. 234-250

20. Introna, L. D., Whitley, E. A. (1997) Against methodism, Exploring the limits of methods, Information Technology \& People, Vol.10, No. 1, pp. 31-45

21. Isoda, S., Yamamoto, S., Kuroki, H., Oka, A. (1995) Evaluation and Introduction of the Structured Methodology and a CASE Tool, Journal of Systems Software, Vol.28, No.1, pp. 49-58

22. Karahanna, E., Straub, D. W., Chervany, N. L. (1999) Information technology adoption across time: A cross-sectional comparison of pre-adoption and postadoption beliefs, MIS Quarterly, Vol. 23, No. 2, pp. 183-213

23. Kwon, T. H., Zmud, R. W. (1987) Unifying the Fragmented Models of Information Systems Implementation, in Boland, R. J., Hirschheim, R. A. (eds.) Critical Issues in Information Systems Research, John Wiley \& Sons, New York, pp. 227-251

24. Lee, J., Kim, S. (1992) The relationship between procedural formalization and MIS success, Information and Management, Vol.22, pp. 89-111

25. Leonard-Barton, D. (1987) Implementing structured software methodologies: a case of innovation in process technology, Interfaces, Vol. 17, No. 3, pp. 6-17

26. McChesney, I. R., Glass, D. (1993) Post-implementation management of CASE methodology, European Journal of Information Systems, Vol. 2, No. 3, pp. 201209

27. Moore, G. C., Benbasat, I. (1991) Development of an instrument to measure the perceptions of adopting an Information Technology innovation, Information Systems Research, Vol. 2, No. 3, pp. 192-222

28. Nandhakumar, J., Avison, D. E. (1999) The fiction of methodological development: A field study of information systems development, Information Technology \& People, Vol. 12, No. 2, pp. 176-191

29. Orlikowski, W. J. (1993) CASE Tools as Organizational change: Investigating Incremental and Radical changes in Systems Development, MIS Quarterly, Vol. 17, No. 3, pp. 309-340

30. Peacham, D. (1985) Structured methods - ten questions you should ask, Data Processing, Vol. 27, No. 9, pp. 28-30

31. Prescott, M. B., Conger, S. A. (1995) Information Technology Innovations: A Classification by IT Locus of Impact and Research Approach, The DATABASE for Advances in Information Systems, Vol. 26, No. 2/3, pp. 20- 42

32. Rai, A., Howard, G. S. (1994) Propagating CASE usage for Software Development: An Empirical Investigation of Key Organizational Correlates, $O M E G A$, Vol. 22, No. 2, pp. 133-147

33. Roberts, T. L., Hughes, C. T. (1996) Obstacles to implementing a systems development methodology, Journal of Systems Management, Vol. 47, pp. 36-40

34. Roberts, T. L., Gibson, M. L., Fields, K. T., Rainer, R. K. (1998) Factors that impact implementing a SDM, IEEE Transactions on Software Engineering, Vol. 24, No.8, pp. 640-649

35. Rogers, E. M. (1995) Diffusion of Innovations, The Free Press, New York 
36. Swanson, E. B. (1994) Information Systems Innovation Among Organizations, Management Science, Vol. 40, No. 9, pp. 1069-1092

37. Tesch, D. B., Klein, G., Sobol, M. G. (1995) Information System Professionals' Attitudes: Development Tools and Concepts, Journal of Systems Software, Vol. 28, No.1, pp. 39-47

38. Vessey, I., Jarvenpaa, S. L., Tractinsky, N. (1992) Evaluation of vendor products: CASE tools and methodology companions, Communications of the ACM, Vol. 35, No. 4, pp. 90-105

39. Wynekoop J.L., Russo N.L. (1997) Studying SDM: an examination of research methods, Information Systems Journal, Vol. 7, pp. 47-65 